MISES: Revista Interdisciplinar de Filosofia, Direito e Economia

ISSN 2318-0811

Volume III, Número 2 (Edição 6) Julho-Dezembro 2015: 501-520

\title{
A Diplomacia Liberal de Joaquim Nabuco
}

\author{
Bruno Gonçalves Rosi*
}

Resumo: Para além de sua carreira como abolicionista, intelectual, escritor e historiador, Joaquim Nabuco teve também uma importante, ainda que breve, carreira diplomática. Sua principal contribuição nesta última foi o deslocamento do eixo diplomático brasileiro da Europa para os EUA. Em geral, este gesto é atribuído ao Barão do Rio Branco, mas, longe de ser apenas um coadjuvante nesta decisão, Nabuco foi um importante formulador da política externa brasileira. Sua visão de política internacional estava em harmonia com sua atuação política anterior, apresentando um otimismo liberal ausente no Barão.

Palavras-chave: Joaquim Nabuco, Liberalismo, Política Externa Brasileira.

\section{The Liberal Diplomacy of Joaquim Nabuco}

Abstract: Besides his career as an abolitionist, intellectual, writer and historian, Joaquim Nabuco had also an important, although short, diplomatic career. His main contribution in this respect was changing the Brazilian diplomatic axis from Europe to the U.S. Usually, this gesture is credited to Barão do Rio Branco, but far from just supporting this decision, Nabuco was an important formulator of Brazilian Foreign Policy. His view of international politics was in tune with his previous political work, showing a liberal optimism that is absent in the Barão.

Keywords: Joaquim Nabuco, Liberalism, Brazilian Foreign Policy.

Classificação JEL: Y8, Z19.

\footnotetext{
"Bruno Gonçalves Rosi possui graduação em história pela Universidade Federal Fluminense (2005), mestrado em Relações Internacionais pela Pontifícia Universidade Católica do Rio de Janeiro (2009) e doutorado em Ciência Política pela Universidade do Estado do Rio de Janeiro (2016). Atualmente é professor auxiliar da Universidade Candido Mendes. Tem experiência nas áreas de História, Relações Internacionais e Ciência Política, com ênfase em História Moderna e Contemporânea e Política Internacional.

E-mail: bruno_rosi@hotmail.com
} 
Joaquim Nabuco (1849-1910) é um importante personagem da história brasileira, frequentemente lembrado por sua militância em favor da abolição e por sua carreira como intelectual, escritor e historiador. Não tão lembrada é a atuação diplomática de Joaquim Nabuco, especialmente sua passagem por Washington como primeiro embaixador do Brasil nos EUA.

Para aqueles que se dedicam superficialmente ao estudo desta dimensão da vida de Joaquim Nabuco, ele pode parecer um mero coadjuvante do Barão do Rio Branco. José Maria Paranhos da Silva Júnior (1845-1912), o Barão do Rio Branco, é uma figura quase mítica no panteão de heróis nacionais brasileiro. Nome de cidade, praças, ruas e avenidas, o Barão é também celebrado pelo Ministério de Relações Exteriores como o diplomata maior do Brasil, o homem por trás do "Instituto Rio Branco", centro de formação dos diplomatas brasileiros, e mesmo da "Casa de Rio Branco", nome pelo qual o Itamaraty é por vezes apelidado. Para além da distinção entre o homem e o mito, as contribuições do Barão para a política externa brasileira foram muitas: consolidou as fronteiras, afirmou o princípio de igualdade jurídica das nações, estabeleceu o princípio de não interferência em países vizinhos, tudo isso e ainda mais "sem fazer nenhuma injustiça e nem derramar uma gota de sangue". E o Barão foi também responsável por mudar o eixo diplomático do Brasil, da Europa para os Estados Unidos, estabelecendo um paradigma que a literatura de Relações Internacionais denomina de Americanismo ${ }^{1} \mathrm{e}$ que permaneceu quase sem contestação até a década de $1950^{2}$.

Entretanto, uma análise mais detalhada demonstra que o Barão não estava sozinho no estabelecimento deste paradigma: gesto cen-

\footnotetext{
${ }^{1}$ Sobre americanismo ver, por exemplo, PINHEIRO, Letícia. Política Externa Brasileira (1889-2002). Rio de Janeiro: Jorge Zahar, 2004.

2 BUENO, C. \& CERVO, A. História da Política Exterior do Brasil. 2. ed. Brasília: Editora Universidade de Brasília, 2002.
}

tral da mudança de eixo da PEB foi elevar a representação diplomática do Brasil nos EUA para o nível de Embaixada, e nomear como primeiro embaixador do Brasil nos EUA o então já ilustre Joaquim Nabuco. Na superfície, o Barão e Nabuco estavam unidos no propósito de fazer dos EUA uma prioridade para a diplomacia brasileira. Um exame mais detalhado revela que eles possuíam americanismos distintos (ainda que não diametralmente opostos): o Barão buscava a aproximação com os EUA em termos predominantemente pragmáticos: não se via impedido, por exemplo, de simultaneamente buscar o Pacto ABC com Argentina e Chile, e principalmente de sustentar a soberania das nações em um sistema internacional por definição anárquico. Já Nabuco procurava emprestar ao monroísmo de Theodore Roosevelt (1858-1919) um sentido coletivo através do apoio ao pan-americanismo. Diferentemente da aparente realpolitik do Barão, ele possuía um americanismo ideológico.

O americanismo pragmático que observo no Barão consiste no seguinte: buscar na política externa brasileira aproximação com os EUA de forma pragmática, ou seja, como um meio, e não como um fim em si mesmo. O Barão buscou na política externa brasileira aproximação com os EUA como meio de alcançar como fim a segurança brasileira num sistema internacional ameaçador, no qual o Brasil não possuía os meios de se defender sozinho. Passado o período de dificuldade do Brasil, ou modificadas as relações de poder no sistema internacional, nada havia que prendesse o Brasil aos EUA. Mas a mudança seria acidental, não essencial: o sistema internacional continua sendo sempre marcado pela anarquia, dilema da segurança e incerteza. Mudam apenas as relações entre as peças nele contidas. Na política interna os EUA não tinham a mesma relevância para o Barão.

$\mathrm{O}$ americanismo ideológico que observo em Joaquim Nabuco consiste no seguinte: buscar na política externa brasileira aproximação com os EUA de forma ideológica, ou seja, como um ideal, um fim em si mesmo. Nabuco também buscou na política externa brasileira aproximação com os EUA como meio de al- 
cançar como fim a segurança brasileira num sistema internacional ameaçador, no qual o Brasil não possuía os meios de se defender sozinho. No entanto, o período de dificuldade do Brasil para se defender não iria passar por uma iniciativa isolada deste ou isolada da "aliança" com os EUA. As relações de poder no sistema internacional iriam se modificar justamente porque o Brasil, em sua aproximação com os EUA, apoiava o surgimento de um novo sistema de poder independente da Europa. Esse projeto de longo (ou eterno!) prazo prendia o Brasil aos EUA. A aproximação com os EUA não era um acidente, mas sim a essência da política externa brasileira e de um novo sistema internacional que se pretendia construir: não mais marcado pela anarquia pura e simples, pelo dilema da segurança e incerteza, mas sim um sistema de regras, normas ou compromissos entre os Estados. A mudança seria bem mais substancial do que um novo posicionamento das peças. Na política interna, os EUA também tinham relevância para Nabuco: ainda que peculiaridades de cada país não fossem ser superadas, os EUA eram um exemplo que o Brasil deveria seguir: havia algo do liberalismo otimista e convicto dos EUA que deveria ser copiado no Brasil.

Resumindo a diferença entre o americanismo pragmático e o americanismo ideológico conforme estou definindo aqui: no americanismo pragmático, política externa e política interna estão separadas; a política externa é uma questão de Estado, a política interna é uma questão de governo. Além disso, a aproximação com os EUA é um meio e não um fim em si mesmo, e sendo assim há a possibilidade de ser uma política de mais breve duração. No americanismo ideológico, política externa e política interna estão em harmonia; a política externa ainda é uma questão de Estado, mas a política interna também. Além disso, a aproximação com os EUA é um fim em si mesmo e, sendo assim, há a expectativa de ser uma política de duração mais longa ${ }^{3}$.

\footnotetext{
${ }^{3}$ SILVA, Alexandra de Mello. O Brasil no Continente e no Mundo: Atores e Imagens na Política Externa
}

Assim como o Barão, Joaquim Nabuco era uma figura pública egressa do Império, e que na República manteve convicções monarquistas, e que por isso mesmo passou por uma espécie de autoexílio conferido nos primeiros anos do novo regime. Também como o Barão, Joaquim Nabuco possuía experiência diplomática anterior: já havia sido inclusive representante do Brasil nos EUA, embora o cargo de embaixador fosse uma criação do Barão. Mas as semelhanças entre os dois começam a parar por aí: embora com idades muito próximas (o Barão nascido em 1845 e Nabuco em 1849), Nabuco tornou-se uma figura nacionalmente conhecida antes do Barão, e não por sua contribuição diplomática: era reconhecido (como é até hoje) pela sua luta pela abolição da escravidão. Outra diferença é que Nabuco havia tido uma carreira política na monarquia, mais precisamente no Partido Liberal. Especialmente significativo é o fato de que Nabuco era filho de José Tomás Nabuco de Araújo Filho (1813-1878), líder tão importante para o Partido Liberal quanto José Maria da Silva Paranhos (1819-1880) (o pai) havia sido para o Partido Conservador.

Partindo desta introdução, o objetivo deste texto é analisar este americanismo ideológico conforme representado por Joaquim Nabuco. O texto situa esta visão de política externa dentro do pensamento político de Nabuco e também dentro de uma tradição de pensamento liberal brasileiro na qual ele estava inserido.

\section{I - NASCIMENTO E INFÂNCIA}

Joaquim Nabuco nasceu em Recife, Pernambuco, em 19 de agosto de 1849, e faleceu em Washington, EUA, em 17 de janeiro de $1910^{4}$. Era filho de Ana Benigna Barreto

Brasileira Contemporânea. Estudos Históricos, Rio de Janeiro, Vol. 8, No. 15 (1995): 13-15.

${ }^{4}$ Os dados biográficos de Joaquim Nabuco apresentados aqui são adaptados a partir de: <http://www.academia. org.br/academicos/joaquim-nabuco $>$. 
Nabuco de Araújo, irmã do marquês do Recife, Francisco Pais Barreto, e do Senador José Tomás Nabuco de Araújo. Seu pai, de origem baiana, se estabeleceu em Pernambuco, onde se tornou juiz e casou com a sobrinha do poderoso marquês do Recife, aliando-se à oligarquia conservadora da província da qual fazia parte a família da esposa, os Pais Barreto. Três integrantes da linha paterna, o tio-avô, o avô e o pai, foram senadores vitalícios do Império. Antes do Senado, o pai exerceu o mandato de deputado em várias legislaturas. Apesar do começo conservador, Nabuco de Araújo se tornou um dos mais importantes líderes do Partido Liberal, várias vezes ministro da Justiça, presidente de província, membro do Conselho de Estado, advogado e jurista de projeção na Corte. Se tornou um "estadista do império", como o filho o chamou, um dos principais líderes luzias de todo o Segundo Reinado ${ }^{5}$.

Joaquim Nabuco passou os primeiros anos de vida afastado da família. Poucos meses após seu nascimento, o pai foi eleito deputado e partiu com a família para o Rio de Janeiro. Joaquim ficou sob os cuidados da madrinha, Ana Rosa Falcão de Carvalho, dona do engenho Massangana. A partir daí costuma-se dizer que ele teve a infância de um príncipe: recebeu para si um preceptor privado e escravo de serviço. Em Minha formação, autobiografia originalmente publicada em 1900, ele lembra de um episódio formativo ocorrido neste período de sua vida: um jovem escravo fugido chega até o engenho e se joga aos seus pés pedindo para ser comprado pela madrinha, de quem receberia melhores tratos. Nabuco afirma mais tarde que, neste episódio, descobriu o que era a escravidão.

Com o falecimento da madrinha, em 1857, Nabuco mudou-se para o Rio de Janeiro. No meio dos quatro irmãos, sentia-se como um órfão. Dois anos depois, o pai decidiu enviá-lo a um colégio interno em Friburgo, dirigido pelo professor bávaro José

${ }^{5}$ NABUCO, Joaquim. Um Estadista do Império. Rio de Janeiro: Topbooks, 1997.
Hermann de Tautphoeus (1810-1890), o barão de Tautphoeus. O aluno e o professor desenvolveram uma admiração mútua. Quando o barão passou a ensinar no Colégio Pedro II, Nabuco o acompanhou. No Pedro II, estudou ao lado do futuro presidente Francisco de Paula Rodrigues Alves (1848-1919), invariavelmente eleito o melhor aluno da instituição. Já Nabuco passou por ali sem brilho especial, graduando-se em 1865.

Do Pedro II, Nabuco foi para a faculdade de Direito de São Paulo. Em sua turma estavam Castro Alves (1847-1871) e Rui Barbosa (18491923), e também os futuros presidentes Rodrigues Alves e Afonso Pena (1847-1909). Nabuco demonstrou pouco interesse pelos estudos jurídicos, mas foi influenciado pelo professor José Bonifácio, o Moço (1827-1886), a adotar o liberalismo progressista como ideologia política. Também manteve intensa atividade nos grêmios políticos e literários e nos jornais da faculdade. De acordo com o costume da época, transferiu-se no quarto ano do curso para o Recife, a fim de ter a experiência do sul e do norte do país.

Em Recife a vida acadêmica seguiu pouco interessante para ele. Em compensação, o retorno à terra natal foi uma fase preparatória essencial para a futura carreira parlamentar: ali, teve contato com o eleitorado da capital pernambucana e com os chefes liberais amigos de seu pai. O interesse pela escravidão também se aprofundou neste período.

\section{II - O АвоLICIONISMo}

A passagem de estudante para líder abolicionista teve um marco significativo com o julgamento do escravo Tomás. Nabuco ainda estava no último ano do curso de Direito quando defendeu este escravo, acusado de assassinar seu amo. Na defesa, Nabuco afirmou que o escravo não havia cometido um crime: havia removido um obstáculo. A defesa foi bem-sucedida o bastante para que Tomás tivesse a pena revertida de execução para trabalhos forçados. E, com o episódio, cresceu a fama de Nabuco. 
Nabuco recebeu o grau de bacharel em 1870, aos 21 anos de idade. Embora estivesse formalmente pronto para seguir os passos do pai e ingressar na carreira parlamentar, esta passagem custou a acontecer: foram oito anos até ser eleito deputado por Pernambuco. Mas preencheu bem o tempo neste período: no Brasil, trabalhou como jornalista em diferentes redações, publicou alguns textos e trabalhou como advogado junto ao pai. Fez também uma viagem para a Europa entre $1873 \mathrm{e}$ 1874, quando conheceu alguns dos maiores intelectuais e políticos do continente e adquiriu por Londres a paixão de toda uma vida.

Nabuco era bastante alto (tinha quase um metro e noventa de altura) e era considerado muito bonito por seus contemporâneos. Era considerado também muito elegante, de hábitos refinados que adquiriu em suas passagens pela Europa. De volta ao Brasil, trazia as novidades da moda masculina, pouco conhecidas por aqui. Seus hábitos aristocráticos facilitavam a circulação pelos salões da época, onde estabelecia contatos políticos. Assim como muitos "construtores da ordem", não tinha muito dinheiro (apesar das origens privilegiadas, parecia ter um talento especial para perder o que ganhava) e sua formação humanística, primeiro no Pedro II e depois nas faculdades de Direito, dava-lhe pouco senso prático para outra coisa que não a carreira pública.

Foi em meio a estas circunstâncias que conheceu Eufrásia Teixeira Leite (1850-1930), uma mulher muito rica, de uma família importante de Vassouras, na província do Rio de Janeiro. Eufrásia era uma mulher moderna: investia na bolsa de Londres em uma época em que as mulheres sequer eram admitidas no pregão. Após a morte dos pais, em 1872, ela e a irmã decidiram morar em Paris. Nabuco a conheceu durante uma viagem de navio para a Europa, em 1873. Daí em diante foram 14 anos de idas e vindas, encontros e desencontros.

Sem perspectiva de conseguir uma eleição parlamentar enquanto durasse o domínio dos conservadores, Nabuco conseguiu ser nomeado adido diplomático em Washington pela Princesa Isabel (1846-1921) em abril de 1876. Nos 14 meses em que esteve nos EUA, passou pouco tempo em Washington: residiu em Nova York e viajou pelo país a maior parte do tempo. Viu-se tentado a seguir na carreira diplomática. Parecia possível pleitear o cargo de adido em Londres graças ao contato com Francisco Inácio de Carvalho Moreira (18151906), o Barão de Penedo, de quem era amigo. Entretanto, no início de 1878 os liberais voltaram ao poder. Nabuco de Araújo faleceu em março, mas não sem antes conseguir dos lideres liberais em Pernambuco o compromisso de incluir o filho na lista de candidatos do partido. O filho foi eleito no último lugar da lista, apesar de ser pouco conhecido na província.

Entre 1879 e 1881, três ministérios liberais se sucederam: Sinimbu, Saraiva e Martinho de Campos. Neste período, os liberais tentaram passar algumas reformas, e aos poucos Nabuco foi se destacando e o tema da abolição ganhando força. Em 1880 ele ajudou a fundar a Sociedade Brasileira contra a Escravidão, e logo se tornou um dos líderes mais destacados do movimento ao lado de André Rebouças (1838-1898) (seu grande amigo) e José do Patrocínio (1853-1905). Nas férias parlamentares entre 1880 e 1881, viajou para a Europa, para buscar apoio do movimento abolicionista em Portugal, Espanha e França, culminando com o encorajamento recebido da Anti-Slavery Society, em Londres.

A posição firme contra a escravidão pesou politicamente contra Nabuco. Sem apoio eleitoral em Pernambuco e diante de uma nova dissolução da Câmara, não obteve um novo mandato. Refugiou-se então em Londres de 1882 a maio de 1884, onde foi correspondente do Jornal do Comércio e consultor jurídico. Mais importante, porém: em Londres, escreveu O Abolicionismo (1883).

Apesar da resistência parlamentar, a ideia abolicionista ganhou espaço nos anos seguintes. Nabuco voltou para o Brasil em 1884 e candidatou-se mais uma vez em Recife. Sua campanha se destacou pelo apelo 
à opinião pública, manifestações de massa e conferências no Teatro Santa Isabel, coisas incomuns na época. As conferências no Teatro foram reunidas sob o nome de Campanha abolicionista no Recife (1885). Mesmo com dificuldades típicas do processo eleitoral da época, conseguiu ser eleito. Encontrou, porém, um parlamento ainda resistente à abolição: o líder conservador Barão de Cotegipe (1815-1889) ofereceu grande oposição aos abolicionistas, com grande radicalização de parte a parte.

Sem perder de vista a abolição, Nabuco apresentou também um projeto instituindo a federação, que passaria a ser sua nova bandeira. Os próximos anos apresentaram dificuldades, inclusive com Nabuco sendo novamente afastado da câmara e levado ao jornalismo. Em 1887, porém, ele teve seu retorno a tempo de presenciar a proclamação da Lei Áurea de 13 de maio de 1888. Também em 1887, ele e Eufrásia Teixeira Leite deram um basta definitivo. Nabuco casou-se com Evelina Torres Soares Ribeiro (1865-1948) em 1889. Ela também era de uma família aristocrática, filha de José Antônio Soares Ribeiro (1836-1906), Primeiro Barão de Inoã, e neta de Cândido José Rodrigues (1816-1877), Primeiro Barão de Itambi. Profundamente religiosa, Evelina influenciou Nabuco a fazer as pazes com o Catolicismo. Ainda na viagem de núpcias a Buenos Aires, Nabuco perdeu quase todo o dote que recebeu com o casamento investindo na bolsa.

A abolição acelerou a chegada da república no Brasil. A Igreja Católica condenou tardiamente a escravidão e, conforme fizera seu pai, Nabuco recusou o título de visconde. Pouco depois, em 1889, chegava o novo regime.

\section{III - Autoexílio e Carreira como Historiador}

Com a proclamação da república, Nabuco se afastou da vida parlamentar. "Guardou por dez anos o luto da monarquia". Refugiou-se em Londres, Paquetá e Botafogo. Muito amigo de Machado de Assis (1839-1908), aju- dou a fundar a Academia Brasileira de Letras, em 1897, onde fez o discurso inaugural e da qual foi secretário-geral perpétuo, cargo que exerceu até 1899 e de 1908 a 1910. Nesta fase de afastamento, ganhou a vida com dificuldade: exerceu também a advocacia (na qual não teve grande êxito) e o jornalismo (colaborou especialmente com O Jornal do Brasil em sua fase monarquista e com a Revista Brasileira). Escreveu também alguns grandes livros e outras obras: Porque Continuo a Ser Monarquista (1890), panfleto em defesa do regime deposto; Balmaceda (1895), biografia do estadista chileno (na realidade um exercício de política comparada entre Brasil e Chile, no qual se percebe o posicionamento monarquista do autor); $A$ Intervenção Estrangeira Durante a Revolta da Armada (1896), trabalho de história diplomática; Um Estadista do Império (lançado em 3 tomos entre 1897 e 1899), biografia do pai (mas que é, na verdade, a história política do país); e finalmente, Minha Formação (1900), um livro de memórias que, mais uma vez, conta uma boa parte da história do império.

\section{IV - Retorno À CARreira Diplomática, o Caso da Guiana e “Conversão" ao Monroísmo}

Embora inicialmente tenha recusado adesão ao regime republicano em processo de consolidação, aos poucos Nabuco foi se afastando de outros monarquistas mais inflexíveis devido a divergências pessoais, por convicções e por razões táticas. Seu monarquismo se tornou puramente intelectual e afetivo. Deu fim ao luto pela monarquia em 1899 e aceitou o convite do Presidente Campos Sales (18411913) para voltar à carreira diplomática, até porque precisava de dinheiro. Tornou-se a um tempo embaixador do Brasil em Londres, o posto diplomático mais prestigiado da época, e enviado extraordinário e ministro plenipotenciário em missão especial na questão do Brasil com a Inglaterra, a respeito dos limites da Guiana Inglesa. 
Nabuco esteve envolvido com a questão da Guiana até 1904. Escreveu quase sozinho e em francês os 18 tomos das memórias nas quais desenvolveu os argumentos a favor do Brasil, mais tarde publicadas sob o título $O$ Direito do Brasil. A defesa foi entregue ao rei Vitor Emanuel III (1869-1947), da Itália, árbitro da questão, em 1903. O laudo arbitral foi expedido em junho de 1904. Apesar da defesa formulada por Nabuco, Vitor Emanuel III considerou insuficientes as provas apresentadas tanto pelo Brasil quanto pela Inglaterra. Dividiu o território entre os dois litigantes utilizando apenas critérios geográficos, com alguma vantagem para a Inglaterra: esta recebeu 19 mil quilômetros quadrados, contra 13 mil do Brasil. Não era uma derrota completa e nem uma perda tão significativa para o Brasil. Conforme escreveu Rubens Ricupero, "levando em conta o diferencial de poder entre os dois países e a doutrina seguida pelo árbitro, era quase um empate técnico". . Mas o resultado foi muito impactante para Nabuco. Em suas próprias palavras, "em questões com a Inglaterra [...] um país fraco como o Brasil pode considerar-se vencedor, quando fica com a metade do que reclamava"7, e sobre Vitor Emanuel III, "se lhe sujeitássemos a nossa soberania sobre dois terços do Brasil, ele diria que não temos direito algum"8.

Além do aspecto pessoal da derrota, Nabuco se alarmou pelo fato de a arbitragem de Vitor Emanuel III ter se baseado nos princípios definidos a propósito do Congo pela Conferência de Berlim de 1885, e não primazia de descoberta e ocupação histórica invo-

6 RICUPERO, Rubens. Joaquim Nabuco e a nova diplomacia. Conferência proferida na abertura do Seminário "Joaquim Nabuco, Embaixador do Brasil". Recife, 19 ago. 2005, p. 9.

${ }^{7}$ Carta de Joaquim Nabuco [1904]. Proc. desconhecida. (Fundaj). Citado em PEREIRA, Paulo José dos Reis. A Política Externa da Primeira República e os Estados Unidos: a atuação de Joaquim Nabuco em Washington (1905-1910). Revista Brasileira de Política Internacional, Brasília, Vol. 48, No. 2 (Dec. 2005): 111128. Cit. p. 11.

${ }^{8}$ NABUCO, Joaquim. Cartas a Amigos, t. II, p.169. Carta a Tobias Monteiro de 18 de junho de 1904. cados pelo Brasil. De acordo com a doutrina utilizada, o único meio reconhecido de adquirir e conservar a soberania seria a exigência de posse atual completa e a ocupação efetiva do território. Respeitando este critério, dois terços do território brasileiro daquele tempo, especialmente a região amazônica, estariam sob perigo. "Com os princípios modernos quanto à soberania de territórios não ocupados, haveria somente no vale do Amazonas campo vastíssimo para o estrangeiro, sem tocar a orla efetivamente apropriada por nós e outras nações" 9 .

A derrota no litígio com a Inglaterra marcou a virada definitiva de Nabuco para o monroísmo. Naquele episódio, ficou patente para ele que o Brasil não tinha chances de competir com os europeus e manter seu território. É principalmente a partir daí que Nabuco passa a entender que somente os EUA e a Doutrina Monroe poderiam proteger o Brasil contra pretensões imperialistas europeias. De acordo com o próprio, "uma política assim valeria o maior dos exércitos, a maior das marinhas, exército e marinha que nunca poderíamos ter"10. A partir disto a doutrina Monroe deveria ser aceita pelo Brasil "como a fórmula exterior da independência do nosso continente, como a lei da nossa órbita internacional à parte da do Velho Mundo"11. O Brasil era "um mundo sobre o qual cada dia mais se dirigem as cobiças das nações que têm fome de terra, das raças que precisam expandir-se"12 e a Doutrina Monroe "uma defesa contra os estrangeiros bona fide, um interdito possessório. Digo que é só isso, mas isso já é sem preço, pois este abrigo criou a segurança, com toda a sua influência benéfica no desenvolvimento de nações que estão, como as nossas, na fase de crescimento

9 "Outro escrito" citado em RICUPERO. Joaquim Nabuco e a nova diplomacia, p. 7 .

${ }^{10}$ Idem. Ibidem, p. 9.

${ }^{11}$ Ofício de Washington - Nabuco para Rio Branco, 30/05/1905 (AHI). Citado em PEREIRA. A Política Externa da Primeira República e os Estados Unidos: a atuação de Joaquim Nabuco em Washington (19051910), p. 11

${ }^{12}$ Carta de Joaquim Nabuco a Nilo Peçanha, 15/10/1906 (Fundaj). Idem. Ibidem, p. 11. 
natural"13. Em outras palavras, o Brasil precisava escolher "entre o monroísmo ou a colonização europeia" 14 .

É importante localizar historicamente esta interpretação de Nabuco. O mundo vivia, então, a era dos Impérios ou do Imperialismo. Tanto Paranhos quanto Nabuco viveram seus anos de maturidade durante o apogeu desta era: estavam próximos dos 40 anos de idade quando a Conferência de Berlim promoveu o desmembramento do Congo e da África, sob a presidência do Chanceler Otto von Bismarck (1815-1898). Caso semelhante se deu com a China, submetida a tratados desiguais e estabelecimento de portos exclusivos para as potências europeias, com o Japão, forçado a se abrir ao comércio e navegação internacionais, com o Império Otomano, desmembrado pelos europeus, com a Indochina, dominada pelos franceses, entre outros exemplos. Mais perto de casa, haviam assistido ao bombardeio de Valparaíso e à tentativa de Napoleão III de conquistar o México para Maximiliano, no momento em que a Guerra de Secessão distraía a atenção dos EUA ${ }^{15}$.

Dentro deste contexto, fica mais fácil entender as palavras do próprio Nabuco:

Minha impressão é que para todos os países da Europa e da América o problema externo tende cada dia mais a sobrepujar os problemas internos e que estamos caminhando para uma época em que a sorte de todos eles sem exceção tem que ser afetada pela solução que tiver o conflito de influência e preponderância entre os grandes sistemas atuais de forças, como sejam a Tríplice e a Dupla Aliança, o Império Britânico, a doutrina de Monroe, etc ${ }^{16}$.

Diante deste contexto, houve uma convergência de ideias entre o Barão e Nabuco. Mesmo antes de tornar-se embaixador, já defendia que

13 Entrevista de Nabuco ao Chicago Tribune de 10/07/1905 (AHI). Idem. Ibidem, p. 12.

${ }^{14}$ RICUPERO. Joaquim Nabuco e a nova diplomacia, p. 6.

${ }^{15}$ Idem. Ibidem, p. 4.

${ }^{16}$ Carta a Campos Sales citada por Carolina Nabuco na biografia do pai (p. 403). "a nossa diplomacia deve ser principalmente feita em Washington". Conforme interpreta Rubens Ricupero:

Representativos do que esse século teve de melhor, fieis ao seu espírito, foram ambos capazes, no entanto, de perceber com maior argúcia do que a maioria dos contemporâneos a aproximação do fim do período de hegemonia da Europa e os primeiros sinais de que o eixo do poder e da diplomacia mundiais derivava em direção aos Estados Unidos. Agiram, portanto, em consonância com essa percepção, eminentemente realista e não idealizada, como quiseram crer muitos dos críticos da nova orientação ${ }^{17}$.

Reirando: a derrota no caso da Guiana foi um ponto de virada para Nabuco. Sua motivação foi, acima de tudo, a segurança do território brasileiro, ameaçada, a seu juízo, por uma tendência jurídica europeia perigosa para o Brasil, exemplificada pela sentença errônea de Vitor Emanuel III, no arbitramento com a Grã-Bretanha ${ }^{18}$. Diante disso, o único meio de tornar seguros dois terços do território brasileiro seria para Nabuco a Doutrina de Monroe. Em suas palavras: "Não vejo nenhuma outra intuição da qual dependa tanto a conservação do nosso grande todo nacional" 19 .

\section{V - WASHINGTON}

Passaram-se poucos meses para que Nabuco pudesse ter a oportunidade de colocar sua teoria em prática. Foi então que o Barão o convidou a assumir a nova embaixada em Washington, em fevereiro de 1905. Os EUA retribuíram o gesto elevando a representação no Rio à embaixada também. Com este gesto o Barão pretendia deslocar o eixo diplomático do Brasil, de Londres para Washington.

\footnotetext{
${ }^{17}$ RICUPERO. Joaquim Nabuco e a nova diplomacia, p. 5.

${ }^{18}$ Idem. Ibidem, p. 7.

${ }^{19}$ COSTA, João Frank da. Joaquim Nabuco e a Política Exterior do Brasil. Rio de Janeiro: Record, 1968. p.48-49.
} 
Nabuco não teve nenhuma ligação com a iniciativa de criar a embaixada, que se deve inteiramente ao Barão, e até expressou dúvidas quanto à conveniência ou oportunidade do gesto. De outras pessoas o gesto do Barão sofreu críticas até mais duras: o Jornal do Brasil de 14 de janeiro de 1905 o chamou de "luxo injustificável", "megalomania condenável", "grave erro de política internacional". Entretanto, apesar das críticas sofridas desde então, o contexto do imperialismo europeu explica a atitude do Barão ${ }^{20}$.

Utilizando as palavras de Rubens Ricupero:

no simbolismo diplomático daquele tempo, a elevação à embaixada era mudança qualitativa das relações entre dois países. Do ponto de vista norte-americano, o ato expressava, pela linguagem simbólica do formalismo protocolar, que o Brasil tornava-se para o governo dos Estados Unidos o principal parceiro da América do Sul. Para o Brasil, além do aspecto central salientado por Rio Branco - o deslocamento do eixo da diplomacia - a escolha para Washington da mais alta expressão do serviço diplomático nacional, de alguém que, além de diplomata, deixara marca de destaque na história e na cultura do país, sublinhava e realçava a importância do gesto ${ }^{21}$.

Mas as vantagens da embaixada vão além do simbolismo: pouco tempo antes da sua criação, durante o conflito do Acre, Assis Brasil, então ministro nos EUA, queixava-se da dificuldade de ter acesso ao presidente dos EUA. Nabuco, ao contrário, não só dispunha da teórica vantagem protocolar, mas, graças a suas qualidades pessoais, conquistou a amizade e admiração intelectual de Theodore Roosevelt ${ }^{22}$. Graças a este prestígio perante o povo e o governo norte-americano, a começar pelo Presidente Theodore Roosevelt e pelo Secretário de Estado Elihu Root (1845-1937), Na-

\footnotetext{
${ }^{20}$ RICUPERO. Joaquim Nabuco e a nova diplomacia, p. 3.

${ }^{21}$ Idem. Ibidem, p. 3.

${ }^{22}$ Idem. Ibidem, p. 3-4.
}

buco foi recebido em diversas Universidades, nas quais proferiu uma série de conferências, sobre cultura brasileira.

Por fim, para além dos aspectos formais e da relação pessoal com Roosevelt, o Barão pretendia utilizar Nabuco para provocar respostas dos monroístas americanos contra atentados ao Brasil. Um dos casos mais emblemáticos neste sentido foi o acidente do Panther, quando o Barão se correspondeu com Nabuco dizendo "Trate de provocar artigos enérgicos dos monroistas contra esse insulto. Vou reclamar [...] condenação formal do ato [...] Se inatendidos, empregaremos a força para liberar o preso ou meteremos a pique a Panther. Depois, aconteça o que acontecer" ${ }^{23}$.

Em 1906, a política americanista do Barão teve uma retribuição significativa: a III Conferência Internacional Americana foi sediada no Rio de Janeiro. Nabuco veio ao Rio de Janeiro presidir a conferência e em companhia trouxe o Secretário de Estado norte-americano Elihu Root (1905-1909). Ambos defenderam o pan-americanismo, no sentido de uma ampla e efetiva aproximação continental.

A fama de Joaquim Nabuco ultrapassou o eixo bilateral Brasil-Estados Unidos: devido ao passado do Barão na Alemanha, a Legação deste país no Rio de Janeiro manteve com ele intensa relação durante toda a sua permanência no cargo de Ministro das Relações Exteriores. Em ofício de 26 de outubro de 1908, ao analisar para Berlim indícios de instabilidade no Governo Afonso Pena, o Ministro alemão comentou também rumores envolvendo o Barão e Nabuco: segundo seu relato, no Rio de Janeiro se dizia que o Barão viria a se afastar do cargo devido a razões de ordem política e de saúde, e que Nabuco seria seu substituto. $\mathrm{O}$ ministro afirmou não acreditar nos rumores, e concluiu a nota sob a ótica dos interesses alemães: "dada a formação inglesa do

${ }^{23}$ COSTA. Joaquim Nabuco e a Política Exterior do Brasil, pg.232. Telegrama do Barão para Nabuco citado em RICUPERO. Joaquim Nabuco e a nova diplomacia, p. 9. 
Senhor Nabuco, ora impregnado de americanismo, isto não representaria de forma alguma um ganho para a Alemanha" ${ }^{24}$. Possível sinal de que a política arquitetada pelo Barão e por Nabuco colhia resultados.

Em 1909 Nabuco, fez uma viagem oficial a Havana, para assistir à restauração do governo nacional de Cuba. Sua saúde começou a se deteriorar pouco depois. Faleceu em Washington, em 17 de janeiro de 1910. Seu corpo foi conduzido, com solenidade excepcional, para o cemitério da capital norte-americana, e depois foi trasladado para o Brasil, no cruzador North Caroline. Do Rio de Janeiro foi transportado para o Recife, sua cidade natal. Em 28 de setembro de 1915, Recife inaugurou, em uma de suas praças públicas, sua estátua.

\section{VI - O AmERicANismo DE JoAquim NABUCO}

Conforme já mencionado, o primeiro contato de Nabuco com os EUA foi como adido da Legação, em 1876. Não foi uma boa primeira impressão. Os EUA viviam então um momento conturbado de sua política interna e Nabuco teceu, então, uma série de críticas fortes à política e aos políticos norte-americanos $^{25}$. No entanto, caminhando para sua chegada à embaixada em 1905, Nabuco reviu suas ideias a respeito dos EUA na mesma medida em que reviu suas ideias a respeito da Europa. Já em 1898, o futuro sistematizador dessa "nova diplomacia" declarava em entrevista ao Estado de São Paulo: "Nós hoje somos uma das muitas incógnitas de um vasto problema: o problema americano. A Europa, a África, a Ásia formam um só todo político. Defronte dessa massa colossal, que se deve chamar europeia, qual é o

${ }^{24}$ CORRÊA, Luiz Felipe de Seixas. O Barão do Rio Branco: Missão em Berlim, 1901/1902. Brasília: Fundação Alexandre de Gusmão, 2009. p. 129.

${ }^{25}$ PEREIRA. A Política Externa da Primeira República e os Estados Unidos: a atuação de Joaquim Nabuco em Washington (1905-1910), p. 9. destino da América do Sul?"26. Especificamente, tentou encontrar uma diretriz que desse sentido ao seu posicionamento de aproximação com os Estados Unidos, especialmente o papel dos EUA no mundo, com Roosevelt no comando da política externa.

Ao apresentar suas credenciais nos EUA, Nabuco já demonstrava uma característica essencial de seu pensamento de política externa: os EUA como definidores do continente americano como uma zona de paz, em contraste com a Europa, uma zona de guerra: "Todos os votos do Brasil são [...] pelo aumento da imensa influência moral que os Estados Unidos exercem e se traduz pela existência no mundo pela primeira vez na história de uma vasta zona neutra de paz e de livre competição humana" ${ }^{27}$. A mesma característica essencial seria enfatizada em outras ocasiões. Um exemplo: "A América, graças à Doutrina Monroe, é o Continente da Paz, e essa colossal unidade pacificadora, interessando fundamentalmente outras regiões da Terra - todo Pacífico a bem dizer - forma um Hemisfério Neutro e contrabalança o outro Hemisfério, que bem poderíamos chamar o Hemisfério Beligerante" 28 . E ainda:

a influência benéfica dos Estados Unidos na história é provada pela existência, pela primeira vez, de uma grande zona Neutra, como é toda a América independente, inclinada para a paz, ao lado de outra massa (a Europa formando agora por controle, alianças, etc., um todo com a África e a Ásia) inclinada para a guerra, real ou eminente ${ }^{29}$.

Rubens Ricupero concorda que a principal característica do pensamento diplomático

\footnotetext{
${ }^{26}$ Entrevista a "O Estado de São Paulo" 1898 (Carolina Nabuco, obra citada, p.403).
27 Discurso de apresentação de credenciais (24/05/05) citado em RICUPERO. Joaquim Nabuco e a nova diplomacia, p. 6.

${ }^{28}$ NABUCO, Joaquim. Discursos e Conferências nos Estados Unidos. Rio de Janeiro: Benjamin Aguila, s/d, p.146-147.

${ }^{29}$ Carta de Joaquim Nabuco a Sr. Hay, 21/06/1905 (AHI). 
de Joaquim Nabuco foi "a criativa elaboração do conceito de um sistema separado das Américas, distinto do europeu e reservado para ser espaço de paz e colaboração, em contraste com a essência agressiva e beligerante do sistema europeu de então" ${ }^{\prime 30}$. De maneira semelhante, Clodoaldo Bueno interpreta que Joaquim Nabuco foi o brasileiro que mais influiu para o reconhecimento da América como um sistema continental distinto e com personalidade internacional própria ${ }^{31}$.

Nesta interpretação, ele era acompanhado pelo Barão:

A verdade é que só havia grandes potências na Europa e hoje elas são as primeiras a reconhecer que há no Novo Mundo uma grande e poderosa nação com quem contar [...]. As definições da política externa norte-americanas são feitas [...] sem ambiguidades, com arrogante franqueza, sobretudo quando visam os mais poderosos governos da Europa, e o que acontece é que estes não protestam nem reagem, antes acolhem bem as intervenções americanas ${ }^{32}$.

Mas havia algo na interpretação de Nabuco que sobrepujava a teoria do Barão: o americanismo não como uma opção, mas como a única opção da política externa do Brasil:

nossa aproximação com os Estados Unidos é uma política que tem [...] a maior de todas as vantagens que possa ter qualquer política - a de não ter alternativas, a de não haver nada que se possa dar em lugar dela, nada que se lhe possa substituir porque a política de isolamento não é uma alternativa e não bastaria para os imensos problemas que espera o futuro deste país ${ }^{33}$.

Nabuco não estava isolado em suas opiniões: era um ícone de uma corrente que acreditava serem os Estados Unidos o grande parceiro brasileiro do momento, corrente

\footnotetext{
${ }^{30}$ RICUPERO. Joaquim Nabuco e a nova diplomacia, p. 6.

${ }^{31}$ BUENO, Clodoaldo. Política Externa da Primeira República. São Paulo: Paz e Terra, 2003. p.166.

32 Paranhos, despacho de 1905 a Washington.

${ }^{33}$ Carolina Nabuco, p. 424.
}

essa que incluía sumidades como Machado de Assis, Euclides da Cunha (1866-1909), Oliveira Lima (1867-1928), Domício da Gama (1862-1925), Silvio Romero (1851-1914), José Veríssimo (1857-1916), Salvador de Mendonça (1841-1913), Graça Aranha (1868-1931) e Rui Barbosa $^{34}$. Ele próprio menciona Tavares Bastos (1839-1875) como um de seus "precursores, preparadores do caminho, semeadores de ideia" 35 .

Outra característica do americanismo de Joaquim Nabuco é a ligação entre esse e a causa da abolição da escravidão defendida anteriormente. Segundo João Frank da Costa, " $a$ obra de aproximação com os Estados Unidos e de plena realização do continentalismo tinha [...] para Nabuco, a mesma importância que outrora a questão capital da abolição" ${ }^{\prime \prime}$. Nas palavras do próprio Nabuco: "Considero data 24 de maio de 1905 [dia em que entrega pessoalmente à Roosevelt suas credenciais de embaixador] tão grande nossa ordem externa quanto 13 de maio 1888 nossa ordem interna [dia da assinatura da Lei Áurea]" ${ }^{\prime 37}$. E ainda: "O destino queria que este resto de vida [...] pudesse ser empregado em uma causa, um serviço, que [...] encheu completamente na minha alma o vazio que aquela grande ideia tinha deixado. Eu me refiro à aproximação entre as duas grandes Repúblicas do Norte e do Sul" ${ }^{38}$. Nabuco era um monarquista reformador: oscilava entre reformismo e conservadorismo, liberdade e ordem, nação e cidadania $^{39}$. Sua atuação em Washington não

${ }^{34}$ PEREIRA. A Política Externa da Primeira República e os Estados Unidos: a atuação de Joaquim Nabuco em Washington (1905-1910), p. 1-2.

${ }^{35}$ NABUCO. Um Estadista do Império, Vol. III.

${ }^{36}$ COSTA, João Frank da. Joaquim Nabuco e a política exterior do Brasil. Citado em RICUPERO. Joaquim Nabuco e a nova diplomacia, p. 2.

${ }^{37}$ Citado em COSTA, João Frank da. Joaquim Nabuco e a Política Exterior do Brasil. Rio de Janeiro:

Gráfica Record Editora, 1968. p. 76.

${ }^{38}$ Nabuco em Gazeta de Notícias de 24 de julho de 1906. Citado em RICUPERO. Joaquim Nabuco e a nova diplomacia, p. 2.

${ }^{39}$ SALLES, Ricardo. Joaquim Nabuco: Um Pensador do Império. Rio de Janeiro: TOPBOOKS, 2002, p. 27-28. 
estava desconectada deste pensamento ou de sua atuação anterior como abolicionista. A atuação como embaixador estava imbuída do mesmo liberalismo humanitário, herdado ainda do combate abolicionista e do seu desdobramento em questões sociais ${ }^{40}$.

\section{VII - A Nova Política Externa Dos EUA}

Dois eventos em particular marcam a virada dos EUA, de um país isolacionista no continente americano, para um país envolvido em questões globais: o primeiro, em 1905, foi a mediação de Roosevelt para pôr fim à guerra russo-japonesa; o segundo, no ano seguinte, foi a participação, pela primeira vez em assunto puramente europeu, extra-hemisférico, na Conferência de Algeciras, após o incidente de Agadir, entre a França e a Alemanha, a respeito do Marrocos. Estes dois eventos, ocorridos nos dois primeiros anos da embaixada de Nabuco, pareciam demonstrar que ele havia acertado: os EUA estavam caminhando para tornar-se uma potência de primeira grandeza em âmbito planetário ${ }^{41}$.

A mediação de Roosevelt em 19041905, que pôs fim à guerra Russo-Japonesa, foi especialmente importante para que Nabuco confirmasse sua opinião $0^{42}$. Escrevendo para Roosevelt ele disse:

$\mathrm{Eu}$ peço que V.Ex. gentilmente aceite a expressão de nossa gratificação e comum orgulho americano pela nobre página que você escreveu na história da civilização. Todo o mundo lerá isso como um prefácio para uma nova Era de paz [...] Nesse sentido você criou para a presidência americana uma função que conquistará para ela a he-

\footnotetext{
${ }^{40}$ PEREIRA. A Política Externa da Primeira República e os Estados Unidos: a atuação de Joaquim Nabuco em Washington (1905-1910), p. 9.

${ }^{41}$ RICUPERO. Joaquim Nabuco e a nova diplomacia, p. 8.

${ }^{42}$ NABUCO. Discursos e Conferências nos Estados Unidos, p. 168.
}

gemonia moral do mundo, a única que pode ser aceita ${ }^{43}$.

A partir de então, Nabuco confirmou a hipótese que havia formulado quando do fracasso no caso da Guiana: os EUA deveriam ser a opção preferencial da política externa do Brasil. Ele foi bastante explicito neste sentido: escrevendo ao amigo Gastão da Cunha (18631927) disse: "manifesto-me monroísta" ${ }^{44}$, e em outra ocasião afirmou que o monroísmo conferia uma "aliança moral" ao continente ${ }^{45}$. Ele "se orgulhava de não haver no serviço diplomático quem o superasse no monroísmo ou no favorecimento à mais intima aproximação com o governo americano" 46 .

Mas os EUA eram um exemplo para o Brasil, ou apenas uma opção de política externa preferencial? Segundo Nabuco, as duas coisas caminhavam juntas: os EUA eram também um exemplo não apenas para o Brasil, mas para toda a América Latina: no contato com os EUA, "a América Latina [...] se impregnaria, em medida diversa, do vosso otimismo, intrepidez e energia"47. Nabuco esperava que houvesse a construção de uma nova identidade nacional brasileira referida na civilização norte-americana ${ }^{48}$. Os Estados Unidos apareciam, assim, por vezes, como um amigo ou modelo a ser seguido, representando a alternativa anti-imperialista ${ }^{49}$.

43 Telegrama de Nabuco a Theodore Roosevelt, 30/08/1905 (AHI). Citado em PEREIRA. A Política Externa da Primeira República e os Estados Unidos: a atuação de Joaquim Nabuco em Washington (19051910), p. 10.

${ }^{4}$ Carta de Joaquim Nabuco a Gastão da Cunha, 14/12/1905 (Fundaj). Idem. Ibidem, p. 12.

${ }^{45}$ NABUCO. Discursos e Conferências nos Estados Unidos, p. 146-147.

${ }^{46}$ RICUPERO. Joaquim Nabuco e a nova diplomacia, p. 2.

${ }^{47}$ NABUCO. Discursos e Conferências nos Estados Unidos, p. 143.

${ }^{48}$ PEREIRA. A Política Externa da Primeira República e os Estados Unidos: a atuação de Joaquim Nabuco em Washington (1905-1910), p. 13.

49 TOPIK, Steven. As Relações entre o Brasil e os Estados Unidos na Época de Rio Branco. In: CARDIM, 
Ao assumir o cargo de embaixador do Brasil nos EUA, Nabuco tomou parte no círculo intelectual norte-americano. Entre outras atividades, participou de conferências em universidades e proferiu palestras a respeito de assuntos variados, nas quais temas da política internacional e possíveis evidências de seu pensamento político internacional vinham à tona. Nas transcrições destes discursos é possível identificar algumas particularidades do americanismo dele.

Um exemplo do que se está dizendo é a palestra intitulada "O Sentimento de Nacionalidade na História do Brasil", proferida perante o Spanish Club da Universidade de Yale, em 15 de maio de 1908. De acordo com Nabuco, o Brasil sempre possuiu um sentimento nacional, desde os tempos de colônia. Este sentimento nacional contribuiu para a manutenção de um grande território, fator muito importante nas relações internacionais ${ }^{50}$. Mas não foi apenas o sentimento nacional que contribuiu para a manutenção do território: diferentes fatores que Nabuco credita à "sorte" ou "favor de Deus" desempenharam papel semelhante ${ }^{51}$, entre estes a Doutrina Monroe ${ }^{52}$. De acordo com ele, a principal característica da nacionalidade brasileira é seu idealismo e, dentro deste idealismo, o americanismo, a percepção de pertencer a um conjunto de países de um mesmo continente, ligados entre si por algo maior do que a geografia ${ }^{53}$. Para ele, os países da América possuem associação indissolúvel, sendo a Doutrina Monroe um exemplo disto ${ }^{54}$.

Carlos Henrique \& ALMINO, João (Orgs.). Rio Branco, a América do Sul e a Modernização do Brasil. Rio de Janeiro: EMC, 2002. p. 424.

${ }^{50}$ NABUCO, Joaquim. Pensamentos soltos. Camões e Assuntos Americanos. São Paulo: Instituto Progresso Editorial, 1949. (Obras Completas: X), p. 433.

${ }^{51}$ Idem. Ibidem, p. 437.

${ }^{52}$ Idem. Ibidem, p. 440.

${ }^{53}$ Idem. Ibidem, p. 441.

${ }^{54}$ Idem. Ibidem, p. 443.
Em palestra intitulada "A Parte da América na Civilização", proferida em conferência na Universidade de Wisconsin, em 20 de junho de 1909, Nabuco retoma os temas já mencionados. Citando (como o título da palestra indica) as contribuições dos EUA para a História da Civilização, identifica "guardar a paz" como uma das principais. Através da Doutrina Monroe, os EUA pressionaram a Europa em favor da paz. Nas palavras de Nabuco, "a América, graças à Doutrina de Monroe, é o continente da Paz" ${ }^{\prime 5}$. Ainda mais, sendo um continente da paz, a América estabelece um equilíbrio com "o outro hemisfério, que poderíamos chamar beligerante" . ${ }^{56}$ No entanto, Nabuco identifica a causa das guerras "nos obstáculos ao engrandecimento nacional", algo que os EUA ainda não haviam experimentado ${ }^{57}$. Os EUA prosperaram sem obstáculos na mesma época em que "o progresso da civilização e, provavelmente, o da ciência" caminhavam para "substituir a Guerra pelo Direito Internacional, ou de destacar a Guerra do Direito Internacional, que é constituído ainda em maior parte por ela". ${ }^{58}$ Assim, segundo Nabuco, o sentimento pacifista dos EUA seria posto à prova quando estes encontrassem o primeiro obstáculo sério ao seu engrandecimento nacional ${ }^{59}$. Somente então os EUA passariam por sua profissão de fé em favor da Paz. E nada serviria melhor como profissão de fé em favor da Paz do que o Pan-americanismo.

Segundo Nabuco, o Pan-americanismo deve sobreviver como parte da política externa norte-americana, independente da Doutrina Monroe. Assim, não só os EUA se identificariam plenamente com a paz, mas também ligariam a ela o resto continente, levando toda a humanidade mais próxima ao tempo em que esta vai renegar a guerra. Em suas pala-

\footnotetext{
${ }^{55}$ Idem. Ibidem, p. 449.

${ }^{56}$ Idem. Ibidem, p. 450.

${ }^{57}$ Idem. Ibidem, p. 450.

${ }^{58}$ Idem. Ibidem, p. 450.

${ }^{59}$ Idem. Ibidem, p. 450.
} 
vras, "para vós e para nós, as palavras Paz e Pan-americanismo são conversíveis". ${ }^{60}$

Na palestra "A Aproximação das Duas Américas", proferida na Universidade de Chicago, em 28 de agosto de 1908, Nabuco apresenta seu americanismo de forma ainda mais explícita. Ele usa um verbo, "americanizar" e o define como infiltração do otimismo, confiança própria e energia dos EUA nos demais países do continente ${ }^{61}$. Segundo Nabuco, os países da América Latina teriam muito a ganhar com o exemplo dos EUA. Já os EUA ganhariam a amizade dos latino-americanos. Em um mundo visto pelas lentes do realismo, amizade pode não parecer um ganho significativo ou mesmo possível. Mas nas relações internacionais propostas por Nabuco, este é o bem mais substancial que os EUA, como vanguarda do continente, podem ganhar. A partir disso, Nabuco imagina uma América unida em uma mesma moral, um mesmo sistema político ${ }^{62}$ e um mesmo destino. Segundo Nabuco, em parte este sonho já estava sendo realizado pelas conferências pan-americanas. Entretanto, ao lado destas, era necessário criar "uma opinião pública pan-americana"63. Ele cita exemplos da existência de uma "opinião pública mundial", capaz de nivelar as sociedades a normas internacionais. E se uma pública mundial, distante e dispersa, tem este poder, muito mais poderá fazer "uma opinião americana uníssona":

Poderia polir até o máximo de perfeição as instituições políticas de todos os Estados Americanos (...) o pertencer à União das Repúblicas Americanas, será, para todas estas, sinônimo de imunidade, não sô contra a conquista estrangeira, mas também contra a arbitrariedade dos próprios governos e a suspensão das liberdades públicas ou individuais $^{64}$.

\footnotetext{
${ }^{60}$ Idem. Ibidem, p. 450.

${ }^{61}$ Idem. Ibidem, p. 464.

${ }^{62}$ Idem. Ibidem, p. 467.

${ }^{63}$ Idem. Ibidem, p. 468.

${ }^{64}$ Idem. Ibidem, p. 469.
}

Ao longo da palestra, Nabuco também foca no que pode ser descrito como um aspecto positivo da Doutrina Monroe: em lugar de apresentá-la negativamente como uma defesa dos interesses dos EUA contra a Europa (como fizeram Eduardo Prado e Oliveira Lima), ele a apresenta como "um instinto americano", "uma intuição de que este mundo novo nasceu com um destino uno" ${ }^{65}$. De acordo com Nabuco, as duas Américas, os EUA e a América Latina, mantiveram-se afastadas uma da outra por tempo demais. Da parte da América Latina o motivo deste isolamento foi o receio de ter um contato mais próximo com os EUA, "em vista da grande diferença entre o poder deste país e o de todas as demais repúblicas americanas"66. "Por seu lado, os Estados Unidos, sendo um mundo em si, e um mundo que cresce dia a dia mais rapidamente, opuseram a qualquer movimento neste sentido a mais forte das resistências - a da indiferença" ${ }^{\prime 67}$. De acordo com Nabuco, o Brasil, por sua vez, vive um caso a parte: sempre teve uma disposição favorável à aproximação com os EUA. Assim como o Barão, rememora a aliança ofensiva e defensiva proposta pelo Brasil aos EUA, logo após a proclamação da Doutrina Monroe em dezembro de 1823, uma vez que os EUA não podiam, por uma questão de justiça, carregar aquela responsabilidade sozinhos. Segundo ele, o Brasil nunca teve motivo para se desviar do espírito dessa proposta, e nunca, tampouco, sofreu qualquer decepção da parte dos EUA. Assim, "não podia ocorrer ao Brasil que outros países tivessem razões, para não adotar a rota por nos seguida desde a Independência" 68 , ainda mais porque os EUA, com sua alta civilização, não poderiam ferir a qualquer nação ${ }^{69}$. Concluindo, Nabuco expressa seu desejo de ver uma América que tolere a diversidade; e também seu desejo de "ver todos os Estados das duas Américas conhece-

\footnotetext{
${ }^{65}$ Idem. Ibidem, p. 466.

${ }^{66}$ Idem. Ibidem, p. 463.

${ }^{67}$ Idem. Ibidem, p. 463-464.

${ }^{68}$ Idem. Ibidem, p. 464.

${ }^{69}$ Idem. Ibidem, p. 464.
} 
rem-se, amarem-se e comungarem como membros de uma única família entre as Nações" 70.

Observa-se que uma característica do pensamento internacional de Nabuco é a crença no progresso, uma característica que pode ser melhor identificada com o liberalismo e com o luzianismo, em contraposição ao conservadorismo saquarema. Nabuco acreditava que o sistema internacional estava passando por uma mudança: o centro de poder estava passando da Europa para a América, ou mais exatamente para os EUA. O Barão enxerga o sistema internacional de forma mais estática: a Europa continua sendo uma ameaça, assim como os vizinhos sul-americanos. Os EUA e o Corolário Roosevelt são uma compensação a estas outras ameaças. Ao olhar para o sistema internacional, o Barão não enxerga um cenário tão diferente daquele enfrentado por seu pai ou por Paulino José Soares de Sousa (18071866), o Visconde do Uruguai. As mudanças são mais circunstanciais do que definitivas. Ao olhar para o sistema internacional, Nabuco enxerga uma verdadeira revolução em curso, e lamenta que seu colega não o acompanhe com as políticas pertinentes ${ }^{71}$. Em outras palavras, olhando para as semelhanças, seria possível classificar ambos, Nabuco e Barão, como realistas na teoria de relações internacionais. Mas há também uma importante diferença entre os dois: Nabuco acredita na mudança no sistema internacional; o Barão é mais reticente neste ponto. A ideia de mudança presente no pensamento de Nabuco combina com a tradição Luzia, liberal. A ideia de permanência (ou de mudanças mais lentas e graduais) presente no pensamento do Barão combina com a tradição Saquarema, conservadora.

Diante destas características, acredito que seria superficial ou mesmo errado classificar Nabuco e o Barão respectivamente como liberal e realista, ou vice-versa, ou ambos dentro de outras categorias da teoria de relações

\footnotetext{
${ }^{70}$ Idem. Ibidem, p. 470.

${ }^{71}$ PEREIRA. A Política Externa da Primeira República e os Estados Unidos: a atuação de Joaquim Nabuco em Washington (1905-1910), p.15.
}

internacionais. Ainda que considere que estas classificações são válidas e pertinentes, penso que, neste caso específico, é possível ir mais a fundo e classificar o Barão como um Saquarema e Nabuco como um Luzia, sem com isso desqualificar a possibilidade das outras taxonomias.

\section{VIII - Desaprovação aos EUA}

No entanto, o americanismo de Joaquim Nabuco também não era idealista, utópico ou ingênuo. Vícios da sociedade e da política externa norte-americana não lhe eram ocultos. A respeito da política externa, João Frank da Costa observa que "Nabuco não aprova a política americana de intervenção na América Central (mas não julgava que tal fato fosse) de natureza a impedir o fortalecimento das [...] relações entre o Brasil e os Estados Unidos". Em carta ao Barão, o próprio Nabuco dizia:

Note você que eu não acompanho as idéias de Mr. Roosevelt sobre ocupação norte-americana, ou outra, de alfândegas, etc, de países sul-americanos. O meu monroismo é mais largo e não me prende a esses expedientes que ele imagina para 'justificar' (...) a doutrina de Monroe perante a Europa ${ }^{72}$.

Quanto à sociedade norte-americana, Nabuco anotou em seu diário em 6 de agosto de 1909:

O maior dos jogos nacionais aqui é amontoar dollars (para os homens) e gastá-los (para as mulheres). Dollar-heaping e dollar-squandering, posso chamá-los. Depois o dar nos negros. Ainda ontem um ministro branco escapou de ser atacado pela mob por ter apertado a mão de um colega preto. Um senador, que deu um bofetão num criado de cor, dizia ao juiz: "I did not strike a man, but a negro". Designam uma mulher de cor num documento de justiça: "A female of the genus africanus (sic)"73.

\footnotetext{
${ }^{72}$ COSTA. Joaquim Nabuco e a Política Exterior do Brasil, p.203.

${ }^{73}$ Diários, Vol. 2, p.460.
} 
Chegou a concluir (eventualmente de forma errônea e exageradamente pessimista) que os EUA terminariam por expelir o preto como cidadão ${ }^{74}$.

Porém, conforme Rubens Ricupero observa, a lucidez e a condenação moral em tais comentários coexistiam com um profundo realismo. Isto pode ser verificado nos comentários de Nabuco a respeito da reação anti-ianque despertada pela conferência de Haia:

Derrotar os Estados Unidos é uma glória néscia para qualquer nação. Deus queira que haja prudência na nossa imprensa, clarividência entre os nossos homens públicos. Há muita coisa que nos irrita, melindra e aborrece por parte dos Estados Unidos, mas devemos compreender que a nossa única política externa é conquistar-lhes a amizade. Não há nenhum país ao qual seja mais perigoso dar alfinetadas, mesmo as de imprensa $^{75}$.

Ainda a respeito de Haia, e do sentimento antiamericano ali despertado, Nabuco escreveu em seu diário: "Não se fica grande por dar pulos. Não podemos parecer grandes, senão o sendo. O Japão não precisou pedir que o reconhecessem grande potência, desde que mostrou sê-lo"76. Esta anotação serve ainda para demonstrar que o programa de política externa de Nabuco era exequível por coincidir com o interesse e a posição notória dos Estados Unidos. Não visava a objetivos utópicos (ou irrealistas) como obter para o Brasil no mundo o reconhecimento de status de poder acima de nossas reais possibilidades. Tratava-se de um programa estritamente defensivo e moderado ${ }^{77}$.

\footnotetext{
${ }^{74}$ RICUPERO. Joaquim Nabuco e a nova diplomacia, p. 12.

${ }^{75}$ Diários, Vol. 2, p.409. Anotação de 4 de setembro de 1907. Idem. Ibidem, p. 12-13.

${ }^{76}$ Diário do Nabuco, anotação em 25 de agosto de 1907. Idem. Ibidem, p. 8.

${ }^{77}$ Idem. Ibidem, p. 7-8.
}

\section{IX - Diferenças entre Nabuco E BARÃo}

Nabuco não enxergava seu papel na embaixada como um projeto de Rio Branco. Em suas palavras, ele se via "chamado a criar esse papel"78. Nas palavras de Luis Viana Filho (1908-1990), o embaixador pretendia "fazer jogo próprio"79. Colocando de outra forma ainda, Nabuco tinha na embaixada uma postura propositiva, queria ver sua autonomia de ação garantida e não tinha intenção de ficar na sombra de Rio Branco, com quem logo surgem alguns conflitos. Segundo Rubens Ricupero "O embaixador em Washington, em particular, sempre mais capaz de teorização e conceituação que o chanceler" ${ }^{\prime 0}$. Citando o mesmo autor, "A personalidade de Nabuco era certamente mais atraída pelas ideias gerais, mais fortemente impregnada de poesia e sentimento religioso que a do Barão e sua natureza generosa e romântica transbordava em eventuais excessos de ênfase ou de confiança" ${ }^{\prime 1}$.

Quando Rio Branco foi convidado em 1906 pelo novo presidente Afonso Pena para continuar no cargo de ministro, Nabuco escreveu parabenizando-o, mas também procurando garantir esta autonomia: "Vejo que você será o ministro. Pelo país estimo, pois você é uma força ao serviço da dele (...) por mim na parte que me é direta felicito-me, pois você não me desconfessará e me dará liberdade de ação, sem a qual nada posso fazer pela amizade Americana" $"$.

\footnotetext{
${ }^{78}$ Carta de Joaquim Nabuco a Graça Aranha, 02/02/1905 (NABUCO, Cartas II, p. 207).

${ }^{79}$ VIANA FILHO, Luís. A Vida de Joaquim Nabuco. São Paulo: Companhia Editora Nacional, 1952. p. 299.

${ }^{80}$ RICUPERO. Joaquim Nabuco e a nova diplomacia, p. 5 .

${ }^{81}$ RICUPERO. Joaquim Nabuco e a nova diplomacia, p. 12.

${ }^{82}$ Carta de Joaquim Nabuco a Rio Branco, 12/10/1906 (AHI). Citado por PEREIRA. A Política Externa da Primeira República e os Estados Unidos: a atuação de Joaquim Nabuco em Washington (1905-1910), p. 7.
} 
Nabuco estava de fato preocupado com a autonomia que recebia do Barão. Alguns meses antes, escrevendo ao amigo Graça Aranha, disse: "O Rio Branco, esse, não me escreve, nem me diz nada, de modo que não posso conjecturar coisa alguma quanto aos planos e pensamento dele" 83 . Na verdade, durante todo o tempo em que esteve na embaixada, Nabuco reclamou da falta de correspondência de Rio Branco $^{84}$. Talvez o melhor exemplo disso seja uma correspondência de Nabuco ao amigo e confidente Hilário de Gouvêa (1843-1923), já em janeiro de 1909. O texto é um pouco longo, porém merece ser citado na íntegra:

Por estes dias sai o Root e não teremos mais outro Root, nem o Brasil outro Roosevelt. Se o Rio Branco me não deixar assinar o tratado de arbitramento com ele, todas as outras repúblicas, e nações do mundo, assinando, sentir-me-ei profundamente humilhado. Há dias ele me dizia que se sentiria quite humiliated, se não assinasse o tratado com o Brasil, tendo-o assinado com as outras repúblicas americanas. Ele dizia isso com bom-humor, eu o digo com mau. E note que ele nos concede um tipo solitário de tratado, pois não queremos assinar o que o mundo inteiro assinou por causa das ideias assentadas do Rio Branco, que já as fez prevalecer sob o Olinto de Magalhães. (Ele foi feliz com o árbitro singular Chefe de Estado, eu não fui). Somos assim Athanasius contra mundum! e isto em matéria de arbitramento! Imagine o Brasil recusando aos Estados Unidos um tratado de arbitramento que o mundo inteiro assinou! Declarando-se inimigo da Corte da Haia, da qual faz parte! Desconhecendo as Convenções que seus delegados assinaram, sob o pretexto de não terem sido ratificadas pelo Congresso, quando é sabido

${ }^{83}$ Carta de Joaquim Nabuco a Graça Aranha, 21/6/1905 (NABUCO, Cartas II, p. 219). Citado em PEREIRA. A Política Externa da Primeira República e os Estados Unidos: a atuação de Joaquim Nabuco em Washington (1905-1910), p. 8.

${ }^{84}$ Cartas de Joaquim Nabuco a Graça Aranha de 21/06/1905 (NABUCO, Cartas II, p. 217-219), 2/2/1906 (NABUCO, Cartas II, p. 242) e 12/11/1908 (NABUCO, Cartas II, p. 321); Carta de Joaquim Nabuco a Cardoso de Oliveira de 22/10/1909 (Fundaj). Idem. Ibidem, p. 8. que o nosso Congresso procura em tudo conformar-se ao que o nosso governo pensa em matéria de relações exteriores.

E se amanhã tivéssemos um conflito com os Estados Unidos, que eles quisessem sujeitar a Haia? Preferiríamos que rompessem relações conosco, como fizeram com Venezuela? No entanto na questão do Amapá, na da Guiana Inglesa, na da Trindade, na da Pante$r a$, na do Peru, na da Argentina, na da Haia, etc, etc, foi neste país que pusemos logo a nossa melhor esperança. Que quer você! O nosso amigo chegou a pensar em substituir o eixo norte-americano de nossa política externa pelo eixo argentino--chileno, e eu tive que pedir ao Presidente e a ele me dispensassem deste cargo em tal caso, para frustrar no início essa infeliz política do "ABC", que o Zeballos logo se encarregou de mostrar o que seria.

Ele deve ir pensando em substituir-me. Além da nossa orientação diferente (ele confia na Alemanha, na França, na Inglaterra, no Chile, na Argentina, não sei em quem mais, e eu só confio nos Estados Unidos), estou cansado e desiludido da minha missão aqui sem acordo completo com ele, e preciso que, como amigo velho, ele vá pensando em dar-me o meu 13 de Maio $^{85}$.

Paradoxalmente, a falta de instruções por parte do Barão apenas reforçou o caráter autonomista que Nabuco entendia que sua missão deveria ter, e acentuou as diferenças entre os dois. Além disso, o perfil "publicitário" de Nabuco acabava transformando em política oficial suas iniciativas individuais. $\mathrm{Na}$ interpretação de Paulo José, os exemplos mais expressivos disso são o incidente da Panther em 1905 e os decorrentes eventos de preparação e realização da III Conferência Panamericana de 1906 que se realizaria no Rio de Janeiro com a visita do secretário de Estado norte-americano Elihu Root. Em ambos os casos, Nabuco deu um tom mais drástico às ideias de Rio Branco no que se refere ao relaciona-

${ }^{85}$ Obras Completas XIV, p. 329-330. A Hilário de Gouvêa CONFIDENCIAL. Brazilian Embassy, Washington, D. C. Janeiro, 19, 1909. Grifo meu. 
mento com os Estados Unidos, incentivando o que chamava de "quase aliança" ou, pelo menos, buscando que o meio internacional percebesse a relação desses países enquanto tal ${ }^{86}$.

Uma diferença entre o embaixador e o ministro também pode ser observada em uma carta de Nabuco ao presidente Rodrigues Alves. Nesta, Nabuco afirmou que seria essencial conseguir uma forte e exclusiva proximidade com os Estados Unidos, no intuito de garantir segurança e estabilidade para o Brasil ${ }^{87}$. Para que fique claro: forte e exclusiva proximidade com os Estados Unidos. Mais do que Rio Branco buscava. Latina. Esta exclusividade seria favorecida por fatores históricos, já que o Brasil já havia demonstrado em várias ocasiões uma identificação com o ideal de solidariedade americana ${ }^{88}$. Ainda segundo ele, "a aproximação entre os dois países [é] nossa única política externa possível. Ela vale mais para mim do que quantos Dreadnought possamos construir [...] Sem ela valeria muito pouco o nosso isolamento" 89 .

Outra diferença entre Nabuco e Rio Branco se dava no prazo de duração do americanismo: enquanto que o Barão dava sinais de adotar o americanismo de forma contingente e temporária, o embaixador em Washington indicava um projeto de muito mais longa duração. A entente entre os dois países (como Nabuco a chamava) só poderia ser criada "cá e lá, sendo longamente preparada de antemão por esforços como os meus"90. Nabuco temia que, com o tempo, o monroísmo pudesse per-

\footnotetext{
${ }^{86}$ PEREIRA. A Política Externa da Primeira República e os Estados Unidos: a atuação de Joaquim Nabuco em Washington (1905-1910), p. 8.

${ }^{87}$ Carta de Joaquim Nabuco a Rodrigues, 16/07/1908 (Fundaj).
}

${ }^{88}$ NABUCO. Discursos e Conferências nos Estados Unidos, p. 133.

${ }^{89}$ Carta reservada de Joaquim Nabuco a Ilanir da Silveira, 31/10/1908 - grifo no original (Fundaj). Citado em PEREIRA. A Política Externa da Primeira República e os Estados Unidos: a atuação de Joaquim Nabuco em Washington (1905-1910), p. 14.

90 Carta reservada de Joaquim Nabuco a Ilanir da Silveira, 31/10/1908 (Fundaj). Idem. Ibidem, p. 14. der força, e então "nesse dia ai de nós, se a nossa amizade não estiver já bem cimentada"91. Especificamente, Nabuco temia que o Barão ficasse satisfeito com uma aproximação muito mais modesta com os EUA. Nesse sentido, Nabuco reclama a seu amigo e confidente Graça Aranha que o Barão mostrava "desconhecer a marcha do mundo e não ter o instinto da nossa própria conservação" $0^{\prime 2}$.

A política do ABC proposta pelo Barão também provocou reação adversa do embaixador. A maneira de Rio Branco ver o papel das três principais potências da América do Sul e sua relação com os EUA pode ser observada no seguinte trecho:

não vejo motivos para que as três principais nações da América do Sul, - o Brasil, o Chile e a Argentina, - se molestem com a linguagem do Presidente Roosevelt [...] ninguém poderá dizer com justiça que elas estão no número das nações desgovernadas ou turbulentas que não sabem fazer bom uso da sua independência ${ }^{93}$.

Ou seja: fazia parte da política externa do Barão o entendimento de que Argentina, Chile e Brasil formavam um "rol à parte" na América do Sul, com relacionamento diferenciado com os EUA. Nabuco não necessariamente discordava do destaque dos três países, mas se opunha veementemente à aliança proposta pelo chanceler. Seu ponto era evitar situações em que o Brasil tivesse de escolher entre os Estados Unidos e a América Latina. Daí a oposição ao $\mathrm{ABC}^{94}$. Repetindo palavras citadas um pouco acima:

O nosso amigo [o Barão] chegou a pensar em substituir o eixo norte-americano de

${ }^{91}$ Carta confidencial de Joaquim Nabuco a Barbosa Lima, 07/07/1907 (NABUCO, Cartas II, p. 277). Idem. Ibidem, p. 14.

${ }^{92}$ Carta de Joaquim Nabuco a Graça Aranha, 28/09/1908 (NABUCO, Cartas II, p. 315).

${ }^{93}$ Despacho reservado para Washington - Rio Branco a Gomes Ferreira, 31/01/1905 (AHI).

${ }^{94}$ RICUPERO. Joaquim Nabuco e a nova diplomacia, p. 10. 
nossa política externa pelo eixo argentino--chileno, e eu tive que pedir ao Presidente e a ele me dispensassem deste cargo em tal caso, para frustrar no início essa infeliz política do "ABC", que o Zeballos logo se encarregou de mostrar o que seria [...] ele [o Barão] confia na Alemanha, na França, na Inglaterra, no Chile, na Argentina, não sei em quem mais, e eu só confio nos Estados Unidos.

O americanismo de Nabuco não era exatamente o mesmo do Barão, mas ambos concordavam nas críticas a determinados aspectos da política externa de Roosevelt. Dirigindo-se a Rio Branco, em carta já citada aqui, Nabuco disse:

Note você que eu não acompanho as ideias de Mr. Roosevelt sobre a ocupação norte-americana, ou outra, de alfândegas, etc., de países sul-americanos. O meu monroísmo é mais largo e não me prende a esses expedientes que ele imagina para "justificar" (é a expressão de Mr. Root, "expedientes" é a minha) a doutrina Monroe perante a Europa, a qual o aperta todos os dias por causa desta "doutrina" e sempre em torno da Venezuela ${ }^{95}$.

Se havia diferenças de opinião entre os dois, havia também semelhanças importantes no que diz respeito às relações internacionais: ambos consideram que o Sistema Internacional é anárquico, ou seja, ambos consideram que não há um árbitro imparcial presidindo as relações entre os Estados; ambos consideram que a sobrevivência dentro do sistema é um objetivo central para os Estados; ambos consideram que há diferenças de poder entre os Estados, ou seja, alguns Estados são mais aptos a garantir sua sobrevivência por meios próprios do que outros. Nabuco e o Barão estão de acordo inclusive a respeito dos ganhos de poder serem relativos dentro do sistema

${ }^{95}$ Carta de Joaquim Nabuco a Rio Branco, 19/12/1905 (NABUCO, Cartas II, p. 238). Citado em PEREIRA. A Política Externa da Primeira República e os Estados Unidos: a atuação de Joaquim Nabuco em Washington (1905-1910), p. 15. internacional: a obtenção de poder por parte de um Estado significa a perda de poder por parte de outro Estado ${ }^{96}$. Exemplificando em termos concretos, ambos desconfiam dos vizinhos como ameaças à segurança nacional (especialmente a Argentina) e defendem juridicamente as diferenças de poder entre os Estados. Seja como for, os "excessos" do americanismo de Nabuco foram em grande parte contidos por Rio Branco ${ }^{97} \mathrm{e}$, apesar de diferenças ocasionais, os dois encontram-se em perfeita sintonia no fundamental e chegavam a utilizar as mesmas palavras para manifestar essa convergência ${ }^{98}$.

\section{X - Conclusão}

Joaquim Nabuco e José Paranhos concordavam em algo essencial: o Brasil deveria priorizar as relações com os EUA em sua política externa. Inclusive a escolha de Nabuco para a embaixada em Washington foi parte fundamental da política que o Barão pretendia implementar. Mas o embaixador não era um mero seguidor das ordens do chanceler: Nabuco tinha suas próprias convicções a respeito de como a política americanista do Brasil deveria ser implementada. E é aí que diferenças entre Nabuco e o Barão podem ser observadas: podiam concordar em algo essencial, mas discordavam em pontos que não eram acidentais.

O americanismo de Nabuco envolvia um senso de mudança ausente no americanismo do Barão. Outra forma de dizer isso é falando que Nabuco era mais otimista a respeito de transformações no sistema interna-

${ }^{96}$ N. do E.: O que, no campo de estudos das Relações Internacionais, seguindo a nomenclatura própria da Teoria dos Jogos, entende-se como "lógica de somazero".

${ }^{97}$ PEREIRA. A Política Externa da Primeira República e os Estados Unidos: a atuação de Joaquim Nabuco em Washington (1905-1910), p. 17.

${ }^{98}$ RICUPERO. Joaquim Nabuco e a nova diplomacia, p. 13. 
cional: a Europa era um continente marcado pela guerra (e, neste sentido, ausência de progresso), mas a América não precisa seguir este caminho. E isso poderia ser alcançado debaixo da liderança dos EUA, que ao mesmo tempo protegiam os países mais fracos do continente com respeito ao imperialismo europeu. $\mathrm{Ou}$ seja: a liderança dos EUA era essencial para alcançar algo maior: um continente de paz. Em outras palavras, a liderança dos EUA não era um fim em si mesmo, mas um meio de alcançar um objetivo maior. Ainda assim, esta liderança não deveria ser questionada dentro do projeto mais amplo sendo colocado em prática.

O Barão dava sinais de adotar o americanismo por um período de tempo mais curto, de forma mais circunstancial. Nabuco dava sinais de buscar um projeto de longo prazo, querendo alterar circunstâncias. Penso que o Barão pode ser chamado de realista-pessimista, e Nabuco de realista-otimista. Não diametralmente opostos, mas com diferenças que não devem ser ignoradas, ainda que diferenças dentro de um mesmo continuum. Estavam inseridos em um mesmo debate de pensamento político, mas não no mesmo lado deste debate: enquanto que o Barão apresentava características de um conservador brasileiro do século 19, de um saquarema, Nabuco apresentava características encontradas na tradição luzia. cos 